\title{
Teaching Materials of Thematic Comics in the 2013 Curriculum Learning in Basic Schools
}

\begin{abstract}
Sarkadi ${ }^{1}$, Alghazali Muhammad Iqbal ${ }^{2}$
Universitas Negeri Jakarta, DKI Jakarta

${ }^{2}$ Institut Agama Islam Bunga Bangsa Cirebon, Cirebon

e-mail: sarkadi@unj.ac.id ${ }^{1}$, m.iqbal@bungabangsacirebon.ac.id ${ }^{2}$

Abstract

Learning material books that are used today, especially in elementary schools (SD) are still full text, resulting in the low motivation of students to read them because they are not or not interesting. This study aims to develop thematic comics as learning materials in the 2013 Curriculum with the theme "Events in Life" and sub-theme 1 "Occupation of the Occupation of Nationality" in the fifth-grade elementary school. This research uses the Research and Development (R\&D) method of the Dick and Carey model which consists of 10 stages. The study was conducted in fifth grade students in five elementary schools in Majalengka Regency. These results state that the thematic comic learning materials developed are suitable for use in the learning process in elementary school and show very good responses. The advantage of this thematic comic learning material is that it can integrate various subject matter into a theme that is presented into a story with various character characters in it. This comic learning material has an attraction for students because it is different from ordinary reading books in which it presents visualization of imaginative and colorful images.
\end{abstract}

Keywords: Teaching Materials, Comics, Thematic.

\section{Introduction}

Learning materials as a source of learning and their current conditions are still changing, which can lead to mistakes for teachers and students as users. Not only that, obstacles also occurred in implementing this new curriculum. One of them is the readiness of teachers to teach students using a thematic model according to the demands of the 2013 Curriculum. Teachers in Indonesia are still unable to adapt to this new condition (thematic learning) because they are accustomed to using a partial curriculum (Istiningsih, 2017). The results of research conducted by Krissandi \& Rusmawan (2015) show that the obstacles in implementing the 2013 curriculum are those of the government, institutions, teachers, parents and students. Obstacles that are of particular concern to researchers are the distribution of books and learning activities in student books such as the use of language in textbooks that are difficult to understand and less effective in improving the learning process (Krisdiana et al., 2014).

Field observations are also carried out to see the reality that occurs in the field. Field observations were carried out in 5 schools, namely SDN Majalengka Kulon I, SDN Majalengka Kulon II, SDN Majalengka Wetan VII, SDN Majalengka Wetan III, and SDN Majalengka Wetan IV. The results of the analysis of learning needs that have been carried out are that the learning material expected by students is a book which contains pictures such as comics so that it can foster students' interest in reading. Students reasoned this because if they were faced with an ordinary book, they would feel less interested in reading it (Observation Data, 2019).

In ordinary books, students argue that the composition of text is more than pictures, and some books are full text. As a result, students' interest in reading decreases. However, it will be different if the composition of images and text is 50: 50 or the composition of images is more than text, of course the results will be different where students will be more interested in reading. As stated by Burmark $L$ in Wong (2013), recent research on the

\footnotetext{
${ }^{*}$ Corresponding author.

Received 12 September 2019; Accepted 30 July 2020; Available online 01 December 2020 (c) 2020 JPI. All Rights Reserved
} 
benefits of using color in presentations shows visual color increases the willingness to read by up to 80 percent; using color can increase motivation and participation by up to 80 percent; color enhances learning and increases retention by over 75 percent. Color visuals increase reading, motivation, and participation by up to $80 \%$. Apart from that, the use of color also enhances learning and increases retention by over $75 \%$.

Elementary school students who are still at the concrete operational stage, are still unable to digest the concept of the material presented in an abstract form, such as in written / verbal form. Therefore, the subject matter to be studied must be packaged in a concrete form (real objects). Considering that the fifth grade elementary school students are at the end of the concrete operational stage, the learning material which is packaged in the form of real objects gradually begins to be conveyed in the form of images, and finally it is actually delivered in verbal (abstract) form.

Visual-based learning is very well applied in SD. Learning with pictures / visuals will be very effective if it is in accordance with the learning styles of students in the class which majority have a visual learning style. In addition, it also needs to be supported by a mature and conceptual learning planning (Aisami, 2015). Learning that combines visual and verbal elements (words) will produce good learning because both have a strong correlation (Bingham et al., 2016), as the Dual Coding theory which can increase students' understanding in understanding a reading text if the text it contains visual and verbal elements that are presented simultaneously (Merc \& Kampusu, 2013).

Based on all the opinions that have been put forward, developing a learning material that combines verbal and visual elements is an excellent solution in dealing with the obstacles faced by the teacher and at the same time fulfilling students' expectations regarding the learning materials used in the learning process in the 2013 Curriculum.

One type of picture story is comic. Comic is an image that is juxtaposed (adjacent, side by side, side by side) with other images in an arranged, sequential, and connected manner to provide information to readers (McCloud \& Martin, 1993). Comics can visualize expressions from the written form of the story into pictures. Comics can be likened to a vehicle that can deliver and accelerate students' understanding in interpreting a reading text so that it does not cause boredom and even tends to enjoy and become more meaningful (Arroio, 2011; Manchester, 2017; Poggiali \& Farrell, 2014).

The development of thematic comic learning materials is also part of the development of learning technology. This effort is a new breakthrough because comics are usually used as a means of entertainment reading. Thus, comic learning materials can be classified into textbooks based on information and communication technology (ICT). The benefits of ICTbased textbooks are that they are more attractive and easy to understand, present multimedia messages, encourage more active and varied learning, more flexible learning, allow dialogical communication, can carry out contextual learning, minimize the negative impact of ICT, are easily reproduced, and are more efficient (Widyastono, 2017).

The research objectives for the development of thematic comics are to find out that thematic comic learning materials are feasible to use; student responses to learning using thematic comics; student learning outcomes after using thematic comics on the theme: "Events in Life" and sub-theme 1: "National events of the colonial period" in grade V SD; and the effectiveness of thematic comics to be used as learning materials.

\section{Method}

The research method used is the research and development method (Research \& Development) of the Dick \& Carey model which includes 10 steps. The ten steps of the Dick \& Carey development model, namely identifying instructional objectives; perform instructional analysis; learner analysis and context; write performance goals; developing assessment instruments; develop learning strategies; developing and selecting teaching materials; designing and conducting formative evaluation of instructions; revise instructions; and designing and conducting summative evaluations (Dick, 81 C.E.).

This research was conducted in 5 schools, namely SDN Majalengka Kulon I, SDN Majalengka Kulon II, SDN Majalengka Wetan II, SDN Majalengka Wetan III, and SDN 
Majalengka Wetan IV. The research sample was class $\mathrm{V}$ in the 5 elementary schools with a total of 148 students. The instruments used in this study were interviews, questionnaires, and tests. The interview instrument was used to obtain data on the results of due diligence from material, media, and language experts. In the interview instrument, the experts will be asked for comments, suggestions, input, criticism, and improvement of any indicators that have not achieved maximum results. Questionnaires are used to obtain data on eligibility results from material, media, language, and student responses, both during individual, small group, and field trials. The test is used to measure the achievement of learning objectives. There are two kinds of tests, namely tests used to determine the achievement of goals before implementing the product (pretest) and after implementing the developed product (posttest). The aim is to find out whether there are significant differences in the learning outcomes.

The data analysis technique in this research is the product feasibility data analysis technique from experts in the fields of language, media, and language by changing quantitative data to qualitative. For data analysis techniques, student responses also change quantitative data into qualitative data, namely the interpretation in table 1 below.

Tabel 1. Student Response Data Analysis Techniques

\begin{tabular}{lll}
\hline \multicolumn{1}{c}{ Range of Average Score } & Interpretation \\
\hline $86-100$ & Very good \\
$71-85$ & Well \\
$56-70$ & Enough \\
$46-55$ & Less \\
$0-45$ & Very less \\
\hline
\end{tabular}

The data analysis technique of student learning outcomes uses the t-test to calculate the effectiveness of learning outcomes before and after using thematic comic learning materials.

\section{Results and Discussion}

The results of the formative evaluation in this study are in the form of an assessment of the eligibility of experts, student responses, and learning outcomes. This product feasibility assessment is intended to determine whether a product (learning material) is feasible or not used in the learning process after passing a series of validations, both theoretical validation and empirical validation. Theoretical validation is validation carried out by experts / experts related to the product. While empirical validation is carried out to see the responses of potential product users, namely students.

Theoretical validation is carried out by experts related to the products used, experts in the fields of language, media and materials. Validation of language experts is aimed at people who have the qualifications and background of language education.

Based on the results of questionnaires and interviews with language experts, it was obtained data and information that the thematic comic learning material products got an average score of 4.6. The indicators that got a score of 5 (score scale 1-5) are presented in Table 2.

Table 2. Results of Language Expert Indicators

\begin{tabular}{lll}
\hline No & Indicators that score 5 & Indicators that score 4 \\
\hline 1. & the writing method is in accordance with the use of language that remains polite; \\
General Guidelines for Indonesian Spelling \\
(PUEBI);
\end{tabular}




\begin{tabular}{lll}
\hline No Indicators that score $\mathbf{5}$ & Indicators that score 4 \\
\hline according to the age level and learning educational values and moral values; \\
ability of students; \\
the language used in the story dialogue in the language used is the language of the \\
comics is straightforward and does not child in everyday life; and \\
mean ambiguous, concise, concise, and \\
$\begin{array}{l}\text { easy to understand; and } \\
\text { use appropriate and clear language in use of appropriate and clear language in } \\
\text { providing instructions for working on providing instructions for using comics } \\
\text { practice questions }\end{array}$
\end{tabular}

As a conclusion, it can be argued that thematic comic learning materials fall into the "very feasible" category and henceforth can be used in elementary school learning after being revised first according to suggestions.

The media expert validation process uses a questionnaire instrument consisting of aspects of media effects on learning strategies and aspects of display of thematic comic books. Based on the results of questionnaires and interviews with media experts, it shows that thematic comic learning materials products get an average score of 4.5 . Indicators that get a score of 5 (score scale 1 - 5) are in Table 3.

Table 3. Media Expert Indicator Results

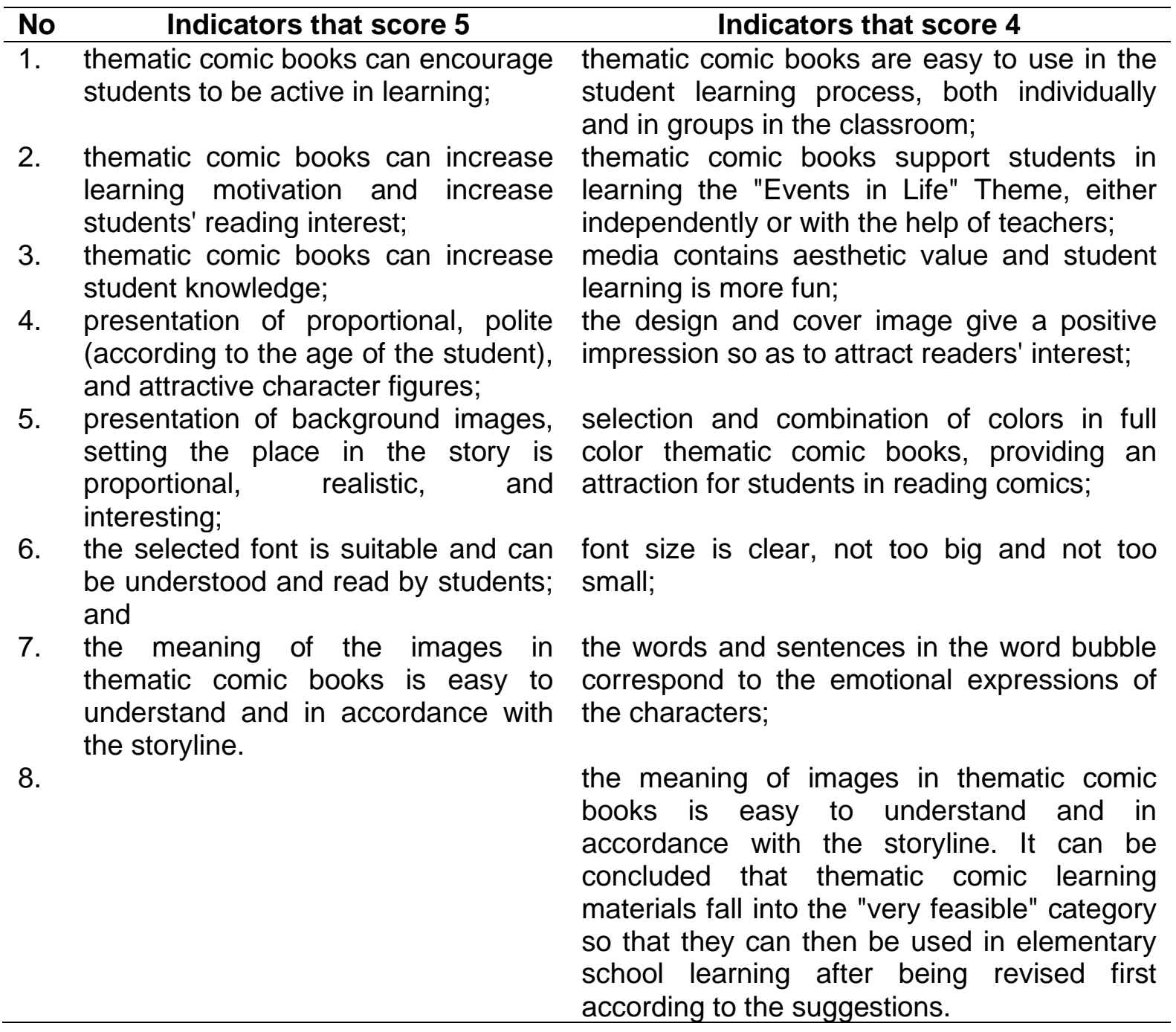


The material expert validation process uses a questionnaire instrument. Based on the validation of the product results through questionnaires and interviews with material experts, it was found that the thematic comic learning material products got an average score of 4.83. Indicators that get a score of 5 (score scale 1-5) are in Table 4.

Tabel 4. Results of Material Expert Indicators

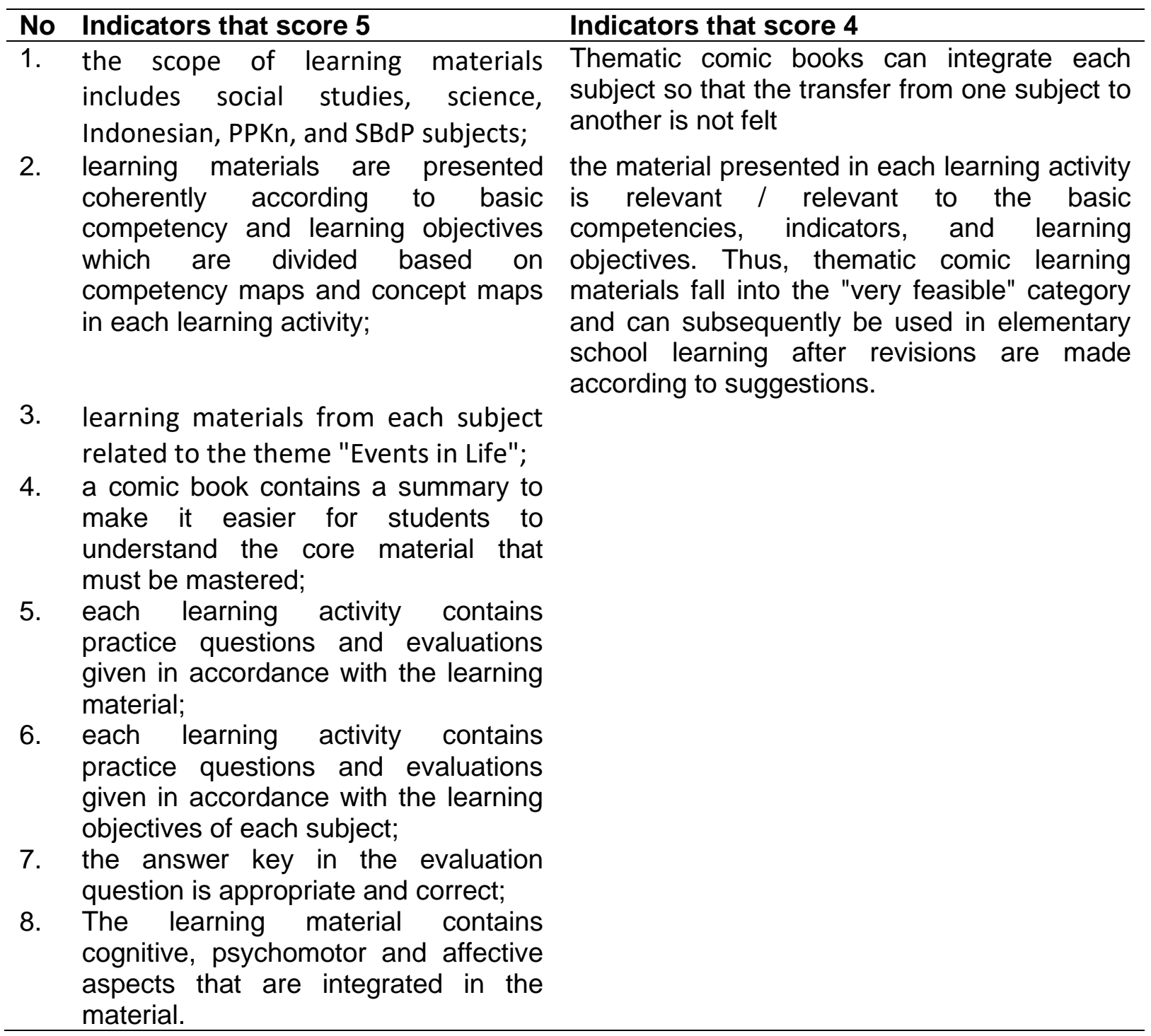

In Diagram 1, the comparison of the results of the due diligence of the experts is presented below. 


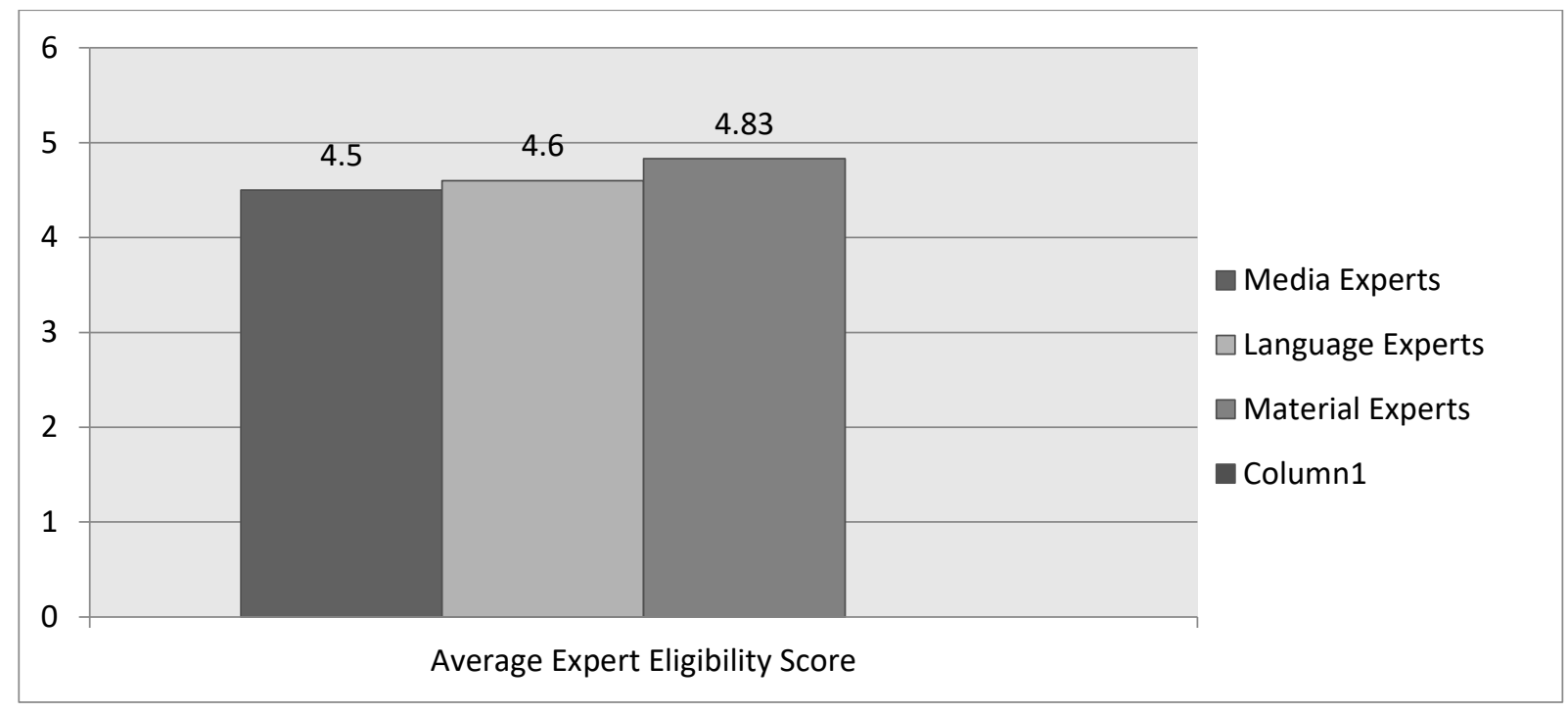

\section{Diagram 1. Average Score of Feasibility Based on Expert Rating}

Individual trials were conducted on 7 students who had high, medium, and low levels of intelligence. The results of the individual test questionnaire showed that the thematic comic learning materials had received a student response with "very good" criteria $(87.2 \%)$. The indicator that gets the highest score is a score of 24 (score scale 1-25), among them, after reading thematic comics, students can find the exemplary attitude of each character in the comic; after reading thematic comics, students can do the questions more easily; and thematic comic learning media and materials are easy to operate. The indicators that get the lowest score, namely a score of 18 , include the appearance of comic books is very interesting and the pictures in the comics make students motivated to read.

Small group trials were conducted on 14 students with low, medium, and high intelligence levels. The results of the small group trial questionnaire showed that thematic comic learning materials had received student responses with the criteria of "very good" $(86.53 \%)$. The next stage was to conduct field trials with a larger number of students. The indicator that gets the highest score is a score of 48 (score scale 1-50), that is, after reading thematic comics, students can do the questions more easily. The indicator that gets the lowest score is a score of 40 , namely students feel that the subject shift is not felt; students like to read thematic comic book learning materials than other learning materials; and pictures in comics make students motivated to read. In Diagram 2 below is a comparison of the percentage results of student responses during the individual test and small group test.

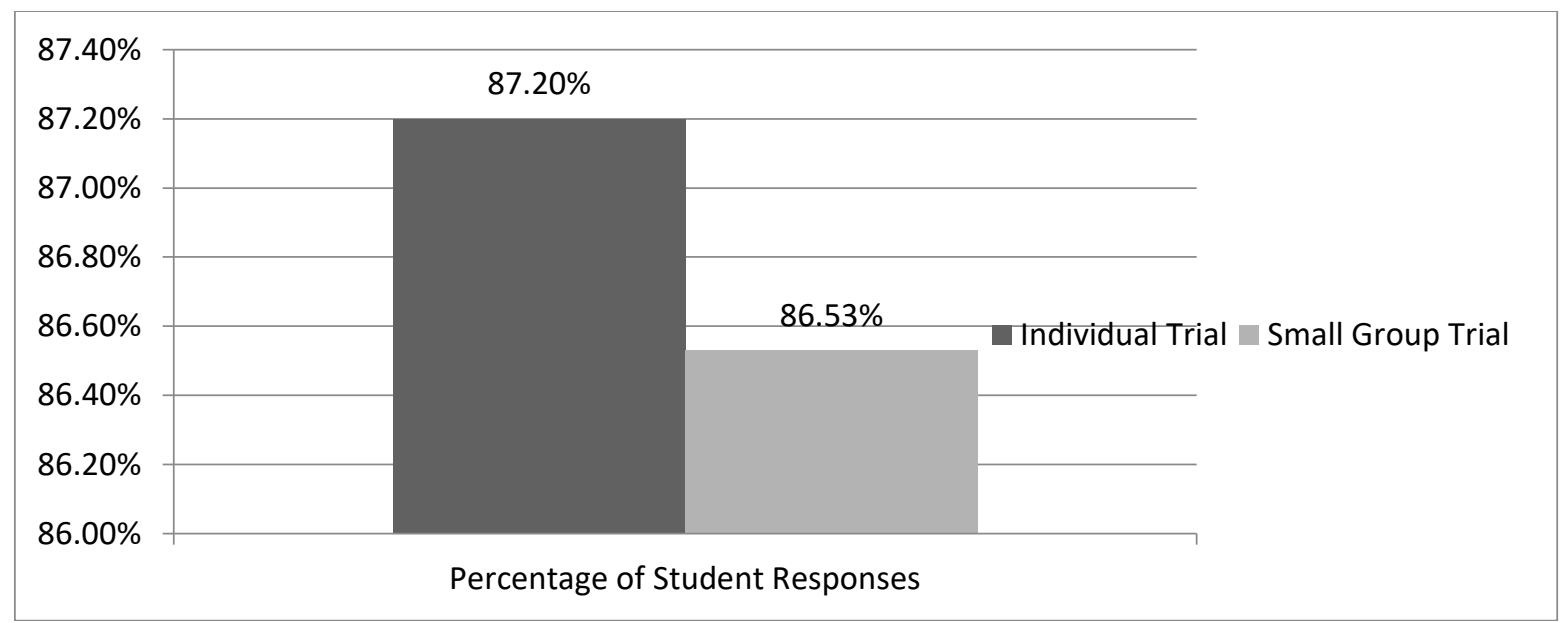

Diagram 2. Percentage of Student Responses 
The effectiveness test can be seen from the difference in the results of the pretest and posttest scores on 140 students from the five elementary schools who participated in the study. Value data were analyzed using t-test. The lowest pretest score obtained was 58 and the highest was 88 . The lowest post-test score obtained was 64 and the highest was 97.

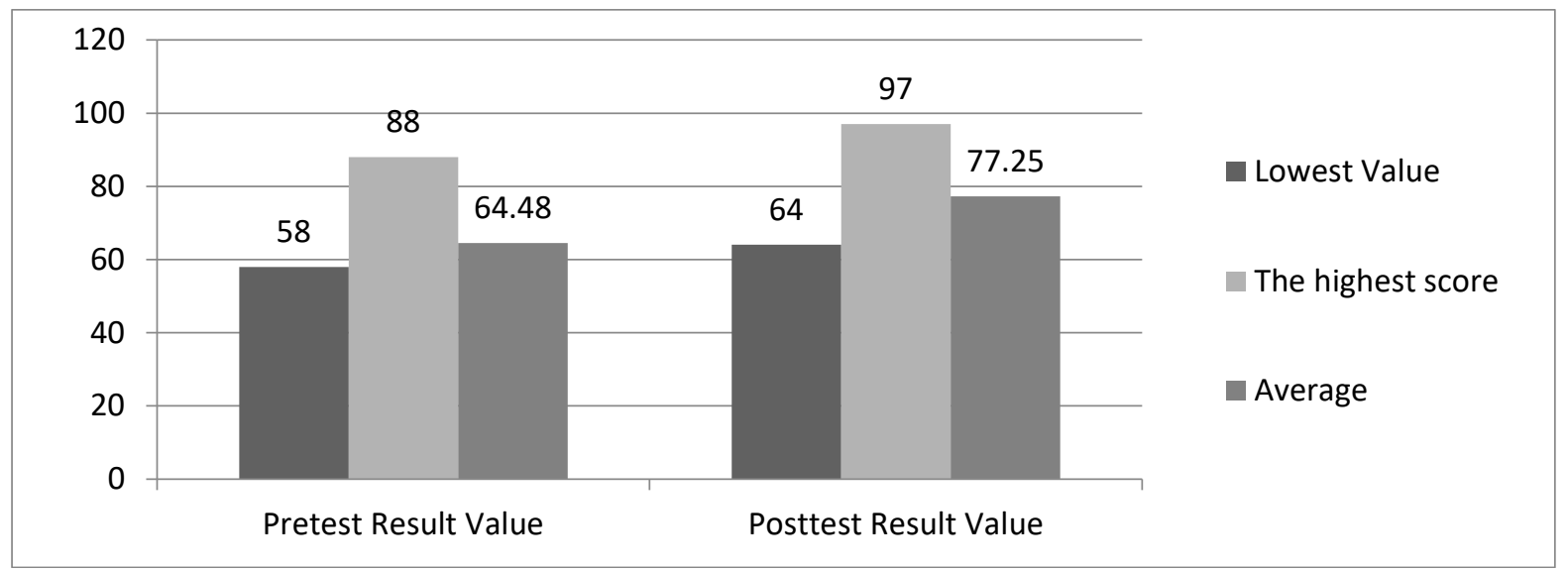

Diagram 3. Average Results of Pretest and Posttest Scores

In Table 5, paired samples statistics show that in learning, the average value of learning outcomes is 64.48 with a standard deviation of 14.23; After using these products, the average value of elementary school student learning outcomes increased to 77.75 with a standard deviation of 13.76 .

Table 5. Paired Samples Statistics

\begin{tabular}{llcccc}
\hline & & Mean & Total & Std. Deviation & Std. Error Mean \\
\hline Pair 1 & Pretes & 64.4822 & 140 & 14.23772 & 1.65387 \\
& Postes & 77.2556 & 140 & 13.76833 & 1.57687 \\
\hline
\end{tabular}

In Table 6 paired samples correlations, the correlation coefficient of learning outcomes scores between before and after being given thematic comic learning materials is 0.689 with a $p$-value of $0.000<0.05$ which means significant.

Table 6. Paired Samples Correlations

\begin{tabular}{ccccc}
\hline & & Total & Correlation & Significance \\
\hline Pair 1 & pretes \& postes & 140 & .678 & .000 \\
\hline
\end{tabular}

In Table 4, paired samples test obtained $t=10.008$ with df 139 and $p$-value 0.000 $<0.05$ or Ho was rejected. Thus, it can be concluded that there are differences in learning outcomes between before and after using thematic comic learning materials.

Table 7. Paired Samples Test

\section{Paired Differences}

\begin{tabular}{|c|c|c|c|c|c|c|c|}
\hline \multirow[t]{2}{*}{ Mean } & \multirow[t]{2}{*}{$\begin{array}{l}\text { Std. } \\
\text { Deviation }\end{array}$} & \multirow{2}{*}{$\begin{array}{l}\text { Std. } \\
\text { Error } \\
\text { Mean }\end{array}$} & $\begin{array}{l}95 \% \\
\text { Interval } \\
\text { Difference }\end{array}$ & $\begin{array}{l}\text { Confidence } \\
\text { of the }\end{array}$ & \multirow[t]{2}{*}{$\mathbf{t}$} & \multirow[t]{2}{*}{ Df } & \multirow[t]{2}{*}{$\begin{array}{l}\text { Sig. } \\
(2- \\
\text { tailed) }\end{array}$} \\
\hline & & & Lowest & Highest & & & \\
\hline
\end{tabular}




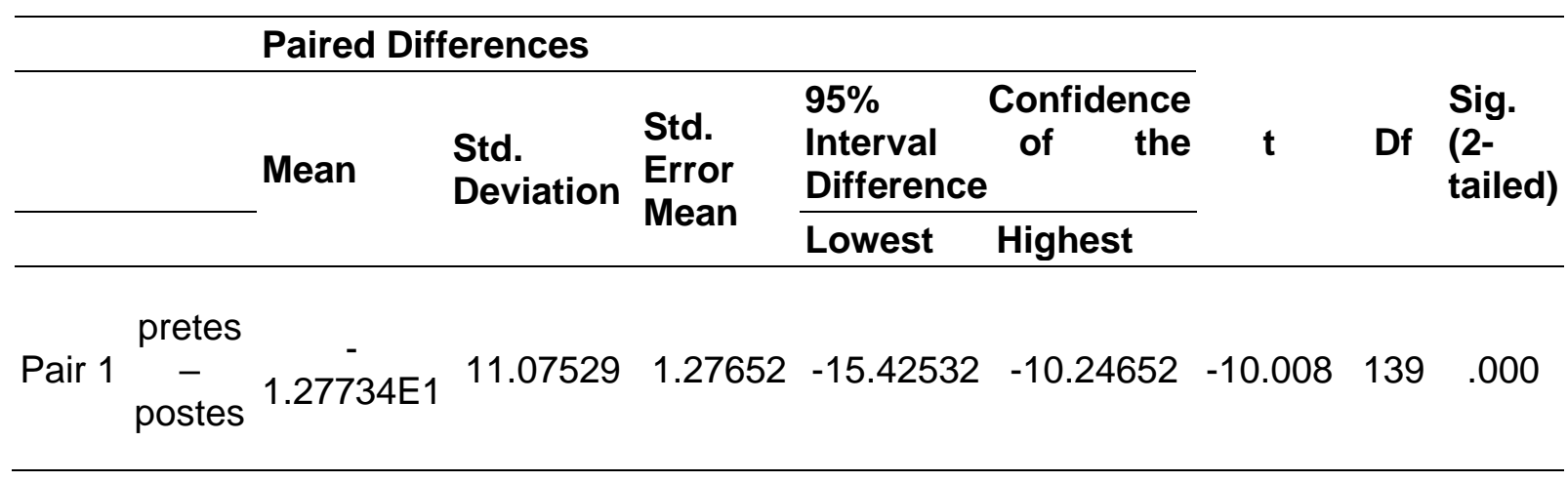

In the implementation of Thematic Comics, there are many advantages, including improving the reading literacy of students, both female students and male students (Kerneža \& Košir, 2016). That is due to the interaction between learning comic media and reading literacy on learning outcomes of elementary school students (Rusmono \& Alghazali, 2019). Students 'reading literacy arises because of the students' enthusiasm for reading. Students realize that comics are completely different from ordinary books. This also means indicating that learning using comics is different from conventional learning where the learning resources are still using ordinary text books. The difference between learning using comics and ordinary conventional learning has been explained by (Raiyn, 2016) that comic media presents different learning from ordinary conventional learning as suggested by that visual learning offers better results than traditional learning systems. A similar opinion was also expressed by (Dunita et al., 2018) that there are differences in learning outcomes after applying comic media to Civics learning compared to conventional conventional learning.

If you look closely, learning comics contains a combination of two elements at once, namely visual elements and verbal elements. These two elements are not owned by ordinary books which are only dominated by verbal elements. The combination of verbal and visual elements in this comic provides more understanding than a reading text which is usually difficult for students to understand because ordinary reading text only contains verbal elements so that it seems abstract (Roswati et al., 2019). The visual elements presented in comics become more understanding to convey messages well so that they can stimulate student activity and creativity as well as increase student response.

If the learning process is filled with enthusiasm and high motivation from students and teachers, it will have a positive impact on the final achievements of students in the learning process, namely student learning outcomes. Many research results show that comics can improve student learning outcomes.

In addition, comics can be a "healing" medium or aid tool in increasing student interest in learning, especially in reading for those who have disabilities (students who are slow) (Arini et al., 2017). The increase in students' motivation and reading interest can be seen in the results of the student response questionnaire data when the individual trials got a percentage of $87.2 \%$ and small group trials got a percentage of $86.53 \%$ with very good criteria. In different conditions, namely in the inclusive class, the concept of learning conveyed through visual media can have an influence on students who have hearing impairments, such as research conducted by (Yuastutik, 2013), that the use of the Picture Mind Plus method for teachers can improve the quality of teacher teaching. and improve student achievement, especially students with hearing impairment. The process of understanding information for deaf children, if supported by a stimulus in the form of images, will be able to help reduce deficiencies in information processing. 


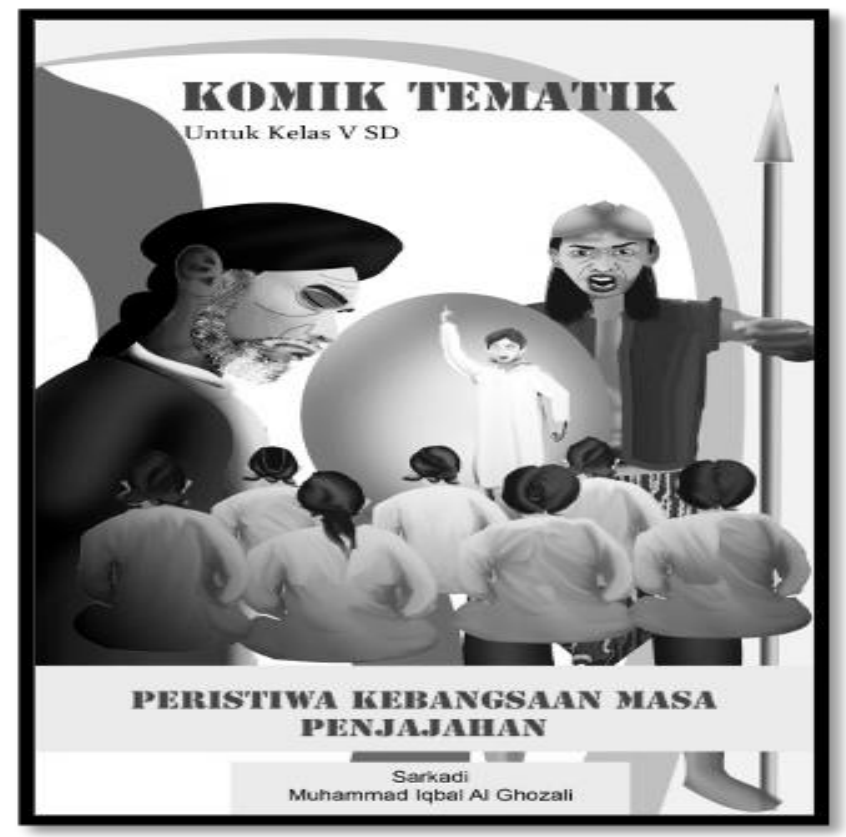

Figure 1. Thematic Comic

The conclusion from all the research results above is related to the ability of comics to increase reading interest, comprehension, analytical skills, criticality, and student participation in group discussions, all of which are included in thematic comic learning materials. The renewal of this thematic comic compared to other comics lies in the content of the story in the comic which is combined with subjects that cover five subjects at once, namely science, social studies, Indonesian, PPKn, and SBdP. Whereas in other learning comics, it usually only covers one subject.

\section{Conclusions}

Thematic comic learning materials are very feasible based on validation from experts such as language, media and material experts. Besides that, thematic comics have also received very good responses from students. There are differences in learning outcomes in learning themed "Events in Life" with sub-theme 1: "National Events of the Colonial Period" between before and after using thematic comic learning materials. The advantage of this thematic comic learning material is that it can integrate various subject content into a theme which is presented into a story with various characters in it. In learning comics books usually only presents one material or one learning content. This comic learning material has an appeal for students because it is different from ordinary reading books in which it presents a combination of verbal and visual elements containing imaginative and colorful images.

\section{References}

Aisami, R. S. (2015). Learning styles and visual literacy for learning and performance. Procedia-Social and Behavioral Sciences, 176, 538-545.

Arini, F. D., Choiri, A. S., \& Sunardi. (2017). The Use of Comic As a Learning Aid To Improve Learning Interest of Slow Learner Student. European Journal of Special Education Research, 2(1), 71-78. https://doi.org/10.5281/zenodo.221004

Arroio, A. (2011). Comics as a narrative in natural science education.

Bingham, T., Reid, S., \& Ivanovic, V. (2016). Paint me a picture: translating academic integrity policies and regulations into visual content for an online course. International Journal for Educational Integrity, 12(1), 1-13.

Dick, W. C. (81 C.E.). L. \& Carey, J.(2009). The systematic design of instruction. NJ: Upper 
Saddle River. Pearson.

Dunita, W. M., Asril, Z., \& Mulyadi, M. (2018). PENGARUH MEDIA KOMIK TERHADAP HASIL BELAJAR PKN PESERTA DIDIK KELAS III SD NEGERI 27 KOTO BARU KABUPATEN PESISIR SELATAN. Al Awlad, 9(1), 85-98. https://ejournal.uinib.ac.id/jurnal/index.php/alawlad/article/view/1623

Kerneža, M., \& Košir, K. (2016). Comics as a literary-didactic method and their use for reducing gender differences in reading literacy at the primary level of education. Center for Educational Policy Studies Journal, 6(2), 125-149. https://eric.ed.gov/?id=EJ1129008

Krisdiana, I., Apriandi, D., \& Setiansyah, R. K. (2014). Analisis kesulitan yang dihadapi oleh guru dan peserta didik sekolah menengah pertama dalam implementasi Kurikulum 2013 pada mata pelajaran matematika (studi kasus eks-karesidenan Madiun). JIPM (Jurnal IImiah Pendidikan Matematika), 3(1).

Krissandi, A. D. S., \& Rusmawan, R. (2015). Kendala guru sekolah dasar dalam implementasi Kurikulum 2013. Jurnal Cakrawala Pendidikan, 34(3).

Manchester, A. (2017). Teaching Critical Looking: Pedagogical Approaches to Using Comics as Queer Theory. SANE Journal: Sequential Art Narrative in Education, 2(2), 2.

McCloud, S., \& Martin, M. (1993). Understanding comics: The invisible art (Vol. 106). Kitchen sink press Northampton, MA.

Merc, A., \& Kampusu, Y. (2013). The effect of comic strips on EFL reading comprehension. International Journal on New Trends in Education and Their Implications, 4(1), 54-64.

Poggiali, J., \& Farrell, R. (2014). Comics to the rescue: finding innovative applications for library digital learning objects.

Raiyn, J. (2016). The Role of Visual Learning in Improving Students' High-Order Thinking Skills. Journal of Education and Practice, 7(24), 115-121. https://files.eric.ed.gov/fulltext/EJ1112894.pdf

Roswati, N., Rustaman, N. Y., \& Nugraha, I. (2019). The Development of Science Comic in Human Digestive System Topic for Junior High School Students. Journal of Science Learning, 3(1), 12-18. https://doi.org/10.17509/jsl.v3i1.18120

Rusmono, R., \& Alghazali, M. I. (2019). Pengaruh Media Cerita Bergambar Dan Literasi Membaca Terhadap Hasil Belajar Siswa Sekolah Dasar. JTP - Jurnal Teknologi Pendidikan, 21(3), 269-282. https://doi.org/10.21009/jtp.v21i3.13386

Widyastono, H. (2017). Pemanfaatan Teknologi Informasi dan Komunikasi pada Sekolah Menengah Pertama Negeri Akreditasi A di Provinsi Jawa Timur. Kwangsan, 5(1).

Wong, K. C. (n.d.). Reflection on Effective Communication for Learning \& Teaching at Higher Learning Institutions.

Yuastutik, I. (2013). Upaya Peningkatan Kinerja Guru Melalui Pelatihan Menggunakan Metode Gambar Pikiran Plus Untuk Meningkatkan Proses Belajar Mengajar Di Sd Inklusif. Kwangsan, 1(2). https://doi.org/https://doi.org/10.31800/jtp.kw.v1n2.p106-121 